\title{
PERSEPSI MASYARAKAT DIENG TERHADAP RUWATAN RAMBUT GIMBAL: SEBUAH TINJAUAN LITERATUR
}

\section{DIENG PEOPLE'S PERCEPTION TOWARDS DREADLOCKS RUWATAN: A LITERATURE STUDY}

\author{
Serafina Indah Chrisanti \\ Universitas Katolik Soegijapranata \\ email: serafinaindah@gmail.com
}

\begin{abstract}
Dreadlocks Shaving Rituals is one of the unique rituals in Indonesia. This ritual is still carried out today because the people of Dieng respect the traditions passed down from their ancestors. Unfortunately, the Dieng people's perception of Dreadlocks Shaving Rituals changed when this ritual was included in the series of Dieng Culture Festival (DCF) events. The existing cultural values are turned into exchange values because of the commodification efforts. The purpose of this study was to determine the length of the dreadlocks in the eyes of the Dieng people. This study uses a qualitative method with a literature review paradigm. Collecting data in this study using documentation techniques that use books and journals according to the research theme. The result of this research is that the people of Dieng have two different perspectives in viewing the dreadlocks before the presence of DCF and after the presence of $D C F$.
\end{abstract}

Keywords: Dreadlocks Ruwatan, Dieng Culture Festival, Literature Review

\begin{abstract}
Abstrak
Ruwatan Rambut Gimbal adalah salah satu ritual unik yang ada di Indonesia. Ritual ini masih dilaksanakan sampai sekarang karena masyarakat Dieng menghormati tradisi yang diwariskan oleh nenek moyang mereka. Sayangnya, persepsi masyarakat Dieng terhadap Ruwatan Rambut Gimbal berubah ketika ritual tersebut masuk kedalam rangkaian acara Dieng Culture Festival (DCF). Nilai budaya yang ada berubah menjadi nilai tukar karena adanya upaya komodifikasi. Tujuan penelitian ini adalah untuk mengetahui Ruwatan Rambut Gimbal dalam kacamata Masyarakat Dieng. Penelitian ini menggunakan metode kualitatif dengan paradigma literature review. Pengumpulan data dalam penelitian ini menggunakan teknik dokumentasi yang menggunakan buku dan jurnal sesuai tema penelitian. Hasil dari penelitian ini adalah masyarakat Dieng memiliki dua kacamata yang berbeda dalam memandang Ruwatan Rambut Gimbal sebelum adanya DCF dan sesudah adanya DCF.
\end{abstract}

Kata Kunci: Ruwatan Rambut Gimbal, Dieng Culture Festival, Literatur Review

\section{PENDAHULUAN}

Berbicara mengenai ritual, Indonesia dikenal karena banyak masyarakatnya memiliki ritual-ritual yang unik. Salah satu ritual tersebut dimiliki oleh masyarakat Dataran Tinggi Dieng. Kawasan Dataran Tinggi Dieng sering disebut sebagai “Negri di Atas Awan" karena terletak pada ketinggian 2.093 mdpl. Kawasan Dataran Tinggi Dieng masuk kedalam Daerah Distrik Tingkat II. Dieng bagian timur atau sering disebut Dieng Wetan masuk dalam wilayah Kabupaten 
Wonosobo dan Dieng bagian barat atau Dieng Kulon masuk dalam wilayah Kabupaten Banjarnegara (Sukanto, 2004).

Letak geografis dan keadaan alam Dataran Tinggi Dieng membuat kawasan ini memiliki banyak tempat sebagai destinasi wisata. Beberapa tempat tersebut diantaranya seperti Telaga Warna, Tuk Bimolukar, Kawah Sikidang dan Candi Arjuna. Tidak hanya destinasi wisata saja, Dataran Tinggi Dieng juga memiliki keunikan lain pada masyarakatnya. Salah satu keunikan pada masyarakatnya adalah keberadaan anak rambut gimbal.

Anak rambut gimbal dianggap sebagai anak yang unik. Hal tersebut dikarenakan tidak semua anak yang lahir di Dataran Tinggi Dieng memiliki rambut yang gimbal. Anak rambut gimbal juga sangat diistimewakan keadaannya karena masyarakat Dieng percaya, anak rambut gimbal adalah titisan dari leluhur yang mereka hormati yaitu Kyai Kolodete (Satria, 2017).

Namun keistimewaan anak rambut gimbal ternyata bukan hanya sebatas keberadaannya saja. Keistimewaan anak rambut gimbal juga terlihat dari perilakunya. Anak rambut gimbal dianggap sebagai anak yang memiliki perilaku lebih nakal daripada anak seusianya yang tidak memiliki rambut gimbal. "Nakal" pada anak rambut gimbal digambarkan oleh perilaku menangis hebat, meronta, merengek, dan mengamuk dalam waktu yang cukup lama. Keinginan mereka juga harus dituruti saat itu juga, jika tidak mereka akan menangis dan mengamuk sekuat tenaganya (Damayanti, 2011)

Hal inilah yang membuat masyarakat Dieng juga mempercayai bahwa tumbuhnya rambut gimbal pada anak juga membawa sukerta. Sukerta adalah marabahaya yang dapat menghampiri anak rambut gimbal dan orang-orang disekitarnya (Febriyanto, 2017). Kekhawatiran akan sukerta yang dapat merugikan tersebut, membuat masyarakat Dieng kemudian melakukan pemotongan rambut gimbal terhadap anak rambut gimbal.

Prosesi pemotongan rambut gimbal ini disebut sebagai Ruwatan Rambut Gimbal. Ruwatan berasal dari Bahasa Jawa ruwat yang artinya membuang sial atau menyelamatkan orang dari gangguan tertentu (BNPB DIY, 2018). Ruwatan rambut gimbal yang dilaksanakan masyarakat Dieng terhadap anak rambut gimbal bertujuan agar sang anak mendapatkan berkat, keselamatan, kesejahteraan, dan ketentraman jiwa.

Pelaksanaan ruwatan rambut gimbal ini biasanya dilaksanakan secara personal dan pribadi. Hal ini disebabkan karena beberapa anak memiliki bebana yang berbeda-beda. Dalam pengertian masyarakat Dieng, bebana adalah permintaan anak rambut gimbal yang dipercaya sebagai suara permintaan dari leluhur mereka. Bebana tersebut disampaikan oleh anak rambut gimbal sebelum melaksanakan ruwatan dan orang tua wajib memenuhi bebana tersebut. Bebana menjadi syarat sebelum melaksanakan ruwatan agar dapat berjalan dengan lancar. Selain itu pemenuhan bebana juga mencegah terjadinya sakit pada anak rambut gimbal.

Sayangnya, segala pelaksanaan Ruwatan Rambut Gimbal yang sudah menjadi budaya dan tradisi ini mengalami pergeseran sejak Ruwatan Rambut Gimbal masuk ke dalam rangkaian acara Dieng Culture Festival (DCF). DCF adalah festival budaya tahunan di Dieng. DCF pertama kali diadakan pada tahun 2010. DCF menampilkan berbagai acara seperti Festival Lampion, Jazz di Atas Awan, dan termasuk di dalamnya juga upacara Ruwatan Rambut Gimbal.

Penjelasan diatas menunjukkan bahwa masyarakat Dieng sebagai pemilik upacara Ruwatan Rambut Gimbal ini telah mengalami dua cara yang berbeda dalam melaksanakan upacara. Yang pertama adalah melaksanakan upacara sesuai dengan tradisi dan yang kedua 
melaksanakan upacara berbarengan dengan diadakannya festival budaya Dieng (DCF) yang dihadiri banyak orang.

Pengalaman yang berbeda ini akan membentuk persepsi yang berbeda terhadap Ruwatan Rambut Gimbal, terutama pada masyarakat Dieng. Persepsi mengenai ruwatan pada masyarakat Dieng ini penting untuk diteliti karena tradisi ini tumbuh secara otentik pada realitas dan dinamika kebudayaan masyarakat tersebut.

\section{Model Komunikasi Interaksi Wilburr Schramm}

Wilburr Schramm membangun sebuah model komunikasi yang menjelaskan bahwa komunikan dan komunikator dalam hal ini adalah masyarakat Dieng saling bertukar pesan mengenai Ruwatan Rambut Gimbal. Wilburr Schramm menekankan bahwa proses komunikasi dalam konteks kebudayaan dapat berjalan dengan baik apabila kedua belah pihak memiliki pengalaman yang sama terhadap pesan yang disampaikan (Liliweri, 2011).

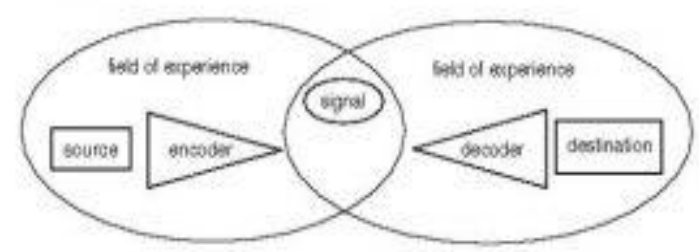

Gambar 1. Model Komunikasi

Sumber: Liliweri, 2011

Dari berlangsungnya proses komunikasi ini maka terbentuklah pandangan atau persepsi dari komunikan dan komunikator. Dalam hal ini, persepsi mengenai Ruwatan Rambut Gimbal masyarakat Dieng yang sudah dilaksanakan sejak dahulu kala dan masih berlangsung hingga saat ini. Meskipun dengan cara pelaksanaan upacara ruwatan yang sudah berbeda.

\section{Pengertian Persepsi}

Persepsi adalah proses dimana orang-orang mengubah kejadian dan pengalaman eksternal menjadi pemahaman internal yang berarti (Samovar, 2010). Persepsi dapat terbentuk karena adanya proses komunikasi yang berlangsung antara satu individu dan individu yang lain.

Dalam hal kebudayaan, budaya sangat berpengaruh terhadap persepsi dan pola interaksi dari seseorang. Selain itu dalam kajian budaya, persepsi dapat terbentuk melalui beberapa hal, di antaranya adalah:

1. Interaksi atau pengamatan

2. Membaca atau menonton sebuah informasi di media massa mengenai budaya

3. Interaksi/cerita dengan generasi sebelumnya

4. Interpretasi simbol yang digunakan dalam sebuah upacara/ritual budaya

Dari berbagai hal tersebut, persepsi dan pandangan masyarakat Dieng terhadap Ruwatan Rambut Gimbal terbentuk. Terbentuknya persepsi juga diperkuat karena mereka memiliki pengalaman yang sama sebagai pemilik upacata Ruwatan Rambut Gimbal. 


\section{METODOLOGI PENELITIAN}

Penelitian ini bertujuan untuk mengetahui bagaimana persepsi masyarakat Dieng terhadap Ruwatan Rambut Gimbal. Dengan demikian penelitian ini menggunakan pendekatan kualitatif, dengan metode literature review. Literature review adalah sebuah metode berupa sebuah pencarian dan merangkum beberapa literatur empiris yang sesuai dan relevan dengan tema (Muslih, 2020). Dalam hal ini temanya adalah Ruwatan Rambut Gimbal.

Literatur yang digunakan bersumber dari Google Scholar, dengan kata kunci pencarian "ruwatan rambut gimbal dieng" (99 hasil), "Dreadlocks Shaving Rituals" (160 hasil) dan "anak rambut gimbal Dieng" (122 hasil) yang dipilah lagi menjadi 10 artikel karena adanya batasan penelitian. Batasan penelitian dalam tema ini adalah:

a. Jurnal yang diambil hanya dari tahun 2009-2019 (karena Dieng Culture Festival pertama dilaksanakan pada tahun 2010).

b. Mengambil jurnal yang membahas mengenai tradisi pemotongan rambut gimbal, upaya komodifikasi, dan hubungannya dengan Dieng Culture Festival.

Dalam metode literature review, terdapat 4 tahap analisis data yaitu Organize, Synthezise, Identify, dan Formulate. Data yang diperoleh adalah jenis data sekunder yang berasal dari buku dan jurnal nasional maupun internasional. Dalam metode literature review, hasil akhir penelitian akan dirumuskan dengan pertanyaan lebih lanjut mengenai tema penelitian yang akan datang.

\section{HASIL DAN PEMBAHASAN}

\section{Pembentukan Persepsi}

Pandangan dan persepsi mengenai Ruwatan Rambut Gimbal dari kacamata masyarakat Dieng tidak terbentuk begitu saja. Dari beberapa literature yang kemudian dianalisis, penulis mengidentifikasi beberapa hal yang berperan dalam membentuk persepsi masyarakat Dieng.

Hal yang pertama adalah mitos. Mitos yang ada dalam Ruwatan Rambut Gimbal ini berasal dari ajaran dan kepercayaan nenek moyang. Mitos ini diwariskan melalui interaksi antar generasi, sehingga karena adanya pengalaman yang sama sebagai masyarakat Dieng, mitos ini dapat dengan mudah dipercaya. Kepercayaan akan kekuatan gaib juga menjadikan mitos ini sebagai pedoman dalam menjalankan kehidupan masyarakat Dieng.

Kedua adalah simbol. Wood (2008) dalam Samovar (2010) mengatakan bahwa manusia menggunakan simbol untuk memberi makna. Dalam Ruwatan Rambut Gimbal simbol tersebut terlihat pada ubarampe yang dipakai saat ruwatan. Membentuk persepsi melalui simbol ini memerlukan kepekaan manusia dalam membaca tanda atau simbol dengan modal memori yang ada pada otaknya. Bekal pengalaman yang sama juga membuat masyarakat Dieng dapat menginterpretasikan simbol dengan lebih baik.

Ketiga adalah interaksi atau perjumpaan. Untuk berkomunikasi dengan orang lain, kita butuh interaksi dan perjumpaan. Persepsi terbentuk karena adanya komunikasi, dan komunikasi akan terjadi ketika ada interaksi dan perjumpaan. Interaksi dan perjumpaan antar masyarakat Dieng ini memungkinkan adanya pertukaran informasi khususnya mengenai Ruwatan Rambut Gimbal. 
Keempat adalah media massa. Media massa membuat masyarakat Dieng memperoleh informasi mengenai Ruwatan Rambut Gimbal entah pada masa lalu, maupun pada masa sekarang. Zaman yang semakin modern dan bertambahnya kebutuhan juga membuat masyarakat Dieng berinovasi untuk memperkenalkan keunikan budayanya pada masyarakat luas. Hal inilah yang turut memengaruhi pembentukan persepsi masyarakat Dieng.

Kelima atau yang terakhir adalah pengalaman empiris. Pengalaman empiris adalah pengalaman yang dirasakan secara langsung oleh seseorang. Mc. Quail dalam bukunya mengatakan bahwa untuk memahami kebudayan kita harus mencarinya, dan ada tiga tempat untuk mencarinya: di dalam masyarakat, di dalam benda (artefak, teks), dan dalam praktik manusia (Mc. Quail, 2011). Pengalaman empiris termasuk kedalam praktik manusia. Pengalaman yang dirasakan secara langsung akan lebih mudah membentuk persepsi seseorang, karena orang tersebut langsung menginterpretasikan hal-hal yang telah dialaminya menjadi sebuah makna.

\section{Proses Pembentukan Persepsi}

Persepsi masyarakat terbentuk melalui sebuah proses komunikasi. Di mana dalam persepsi Masyarakat Dieng terhadap Ruwatan Rambut Gimbal ini dapat dijelaskan terbentuk melalui Model Komunikasi Interaksi Wilbur Schramm. Wilbur Schramm mengatakan bahwa komunikasi akan berjalan efektif apabila pengirim dan penerima pesan memiliki pengalaman yang sama.

Dalam hal Persepsi Masyarakat Dieng terhadap Ruwatan Rambut Gimbal, persepsi ini terbentuk melalui beberapa sumber yaitu: interaksi/perjumpaan, mitos, simbol, media massa, dan pengalaman empiris yang sudah dijelaskan di atas. Sumber-sumber tersebut mengirim dan menyampaikan pesan kepada tujuannya, dalam hal ini Masyarakat Dieng untuk membentuk persepsi mengenai Ruwatan Rambut Gimbal. Sehingga pada akhirnya karena kesamaan pengalaman tersebut, peneliti menemukan ada dua persepsi mengenai Ruwatan Rambut Gimbal yaitu Ruwatan Sebagai Tradisi dan Ruwatan Sebagai Upaya Komodifikasi.

Adanya dua persepsi yang berbeda terhadap Ruwatan Rambut Gimbal ini menunjukkan bahwa Ruwatan Rambut Gimbal mengalami persegeran makna. Beberapa bukti pergeseran makna tersebut dapat dilihat pada tabel berikut.

Tabel 1. Pergeseran Makna Ritual Pemotongan Rambut Gimbal

\begin{tabular}{|l|l|}
\hline \multicolumn{1}{|c|}{ Sebelum DCF } & \multicolumn{1}{c|}{ Setelah DCF } \\
\hline $\begin{array}{l}\text { Ritual diadakan bertepatan dengan } \\
\text { malam satu suro }\end{array}$ & $\begin{array}{l}\text { Ritual diadakan bertepatan dengan } \\
\text { tanggal diadakannya DCF }\end{array}$ \\
\hline $\begin{array}{l}\text { Ritual dilaksanakan di rumah masing- } \\
\text { masing }\end{array}$ & $\begin{array}{l}\text { Ritual dilaksanakan di pelataran Candi } \\
\text { Arjuna }\end{array}$ \\
\hline $\begin{array}{l}\text { Ritual hanya dihadiri oleh pemangku } \\
\text { adat, tetangga, dan keluarga dekat }\end{array}$ & $\begin{array}{l}\text { Ritual dihadiri oleh banyak sekali } \\
\text { wisatawan lokal maupun mancanegara }\end{array}$ \\
\hline $\begin{array}{l}\text { Anak rambut gimbal dicukur oleh } \\
\text { pemangku adat atau siapapun yang dia } \\
\text { minta }\end{array}$ & $\begin{array}{l}\text { Anak rambut gimbal dicukur oleh } \\
\text { Bupati sebagai simbolisasi }\end{array}$ \\
\hline
\end{tabular}

Sumber: olahan data peneliti 
Adanya pergeseran makna pada Ruwatan Rambut Gimbal ini menjadi tantangan baru bagi masyarakat Dieng dan Pemerintah Daerah setempat untuk senantiasa menjaga kesakralan budaya asli daerah. Sehingga budaya ini tidak akan pernah luntur dan lestari.

\section{Persepsi Masyarakat Dieng Terhadap Ruwatan Rambut Gimbal}

Ruwatan rambut gimbal disebut sebagai salah satu praktik kepercayaan yang menjadi identitas masyarakat Dieng (Holis, 2016). Praktik kepercayaan tersebut berangkat dari kepercayaan masyarakat Dieng yang meyakini bahwa ritual yang dijalankan bertujuan baik untuk anak rambut gimbal, yaitu membebaskan mereka dari sukerta. Selain itu, menjalankan ritual itu sampai selesai dan lancar membuat orang tua dan anak rambut gimbal memiliki kebanggan dan ketenangan batin tersendiri.

Pelaksanaan Ruwatan Rambut Gimbal ini melibatkan beberapa pihak seperti anak rambut gimbal, orang tua anak rambut gimbal, pemangku adat, dan masyarakat Dieng sendiri. Merekalah yang sering berinteraksi satu sama lain, terutama disaat akan atau sedang melaksanakan Ruwatan Rambut Gimbal. Dari hasil interaksi inilah muncul persepsi masyarakat Dieng terhadap Ruwatan Rambut Gimbal.

Seperti yang dikatakan oleh Muhammad (29 tahun), warga Desa Parikesit, Dieng. Muhammad dahulunya adalah seorang anak rambut gimbal yang mengikuti Ruwatan untuk memotong rambut gimbalnya. Muhammad meyakini bahwa ada campur tangan kekuatan gaib dalam Ruwatan Rambut Gimbal. Muhammad pernah mencoba memotong rambut gimbalnya sendiri tanpa mengikuti ritual. Namun setelah itu, dia mengalami sakit dan rambut gimbalnya tumbuh lagi. Sejak saat itulah, Muhammad percaya bahwa dia harus memotong rambut gimbalnya melalui upacara Ruwatan Rambut Gimbal sebagai tradisi yang diturunkan oleh nenek moyangnya (Arif dan Fatturahman, 2013).

Selain Muhammad, ada juga Azizah ( 5 tahun) dan ayahnya yang bernama Pak Sukirno. Azizah adalah seorang anak rambut gimbal. Sebelum melaksanakan Ruwatan Rambut Gimbal, Azizah meminta bebana kepada orang tuanya berupa daging sapi goring dan 10 bungkus mie instan. Pak Sukirno selaku orang tua Azizah langsung mengabulkan permintaan putrinya tersebut. Pak Sukirno memandang bahwa mengabulkan bebana adalah hal yang wajib dilakukan sebelum melaksanakan ritual, agar ritual diberkati dan direstui oleh leluhur mereka (Soehadha, 2013).

Kepercayaan mengenai Ruwatan Rambut Gimbal sebagai tradisi nenek moyang yang harus dipatuhi peraturannya juga diamini oleh salah satu tetua adat bernama Mbah Rusmanto. Sebagai salah satu tetua adat, Mbah Rusmanto meyakini bahwa Ruwatan Rambut Gimbal harus dilaksanakan seturut dengan restu dari leluhur mereka, Kyai Kolodete. Itu sebabnya sebelum melaksanakan Ruwatan Rambut Gimbal, Mbah Rusmanto melakukan perjalanan spiritual terlebih dahulu.

Mbah Rusmanto akan melakukan perjalanan spriritual ke Tuk Bimolukar, lalu ke Puncak Gunung Kendil untuk menghaturkan caos dhahar (sajian makan) kepada Kyai Kolodete. Terakhir Mbah Rusmanto akan bertapa di Mandalasari Gua Semar untuk menunggu bisikan nasehat dari Semar Bodroyono. Semar Bodroyono dipercaya sebagai dewa yang mengayomi umat manusia.

Beberapa hal diatas menunjukkan bahwa masyarakat Dieng memiliki persepsi yang sama terhadap Ruwatan Rambut Gimbal sebagai tradisi. Ritual ini adalah sebuah bentuk penghormatan pada leluhur mereka. Dalam melaksanakan Ruwatan Rambut Gimbal, 
masyarakat Dieng juga memiliki kepercayaan bahwa anak rambut gimbal adalah anak yang istimewa. Mereka memiliki hak otonomi untuk meminta bebana dan permintaan lain sebelum melaksanakan Ruwatan Rambut Gimbal. Sebagai sebuah identitas budaya, masyarakat Dieng menyadari bahwa mereka harus melaksanakan Ruwatan Rambut Gimbal secara konsisten sampai sekarang.

Namun sejak masuk ke dalam rangkaian acara Dieng Culture Festival, persepsi masyarakat Dieng menjadi berubah. Masuknya Ruwatan Rambut Gimbal ke dalam rangkaian acara DCF menjadi salah satu upaya dari Kelompok Sadar Wisata (Pokdarwis) Dieng Pandawa untuk tetap menjaga eksistensi ruwatan tersebut. Selain untuk menjaga eksistensi, masuknya ruwatan kedalam rangkaian acara DCF juga disebut untuk memenuhi keinginan masyarakat Dieng dalam memperkenalkan keunikan budayanya pada masyarakat luas.

Pokdarwis Dieng sebagai pihak yang mencetuskan adanya DCF mengatakan bahwa menurut mereka, masuknya Ruwatan Rambut Gimbal ke dalam rangkaian acara DCF akan meningkatkan perekonomian masyarakat dan juga Pendapatan Asli Daerah (PAD). Keunikan dari prosesi ruwatan menjadi salah satu nilai tambah untuk menarik minat wisatawan. Bertambahnya wisatawan yang datang, berarti bertambah juga pemasukan untuk daerah dan masyarakat Dieng.

Sayangnya, upaya tersebut mendapatkan sedikit pertentangan dari beberapa masyarakat Dieng yang lain. Sejak masuk ke dalam rangkaian acara DCF, kesakralan Ruwatan Rambut Gimbal menjadi berkurang. Selain itu juga bentuk ritual yang biasanya personal menjadi ritual publik. Hal ini dikarenakan DCF adalah sebuah festival yang bersifat publik dan dihadiri oleh banyak orang, sehingga pelaksanaan Ruwatan Rambut Gimbal juga akan dilihat oleh banyak orang.

Perubahan kesakralan tersebut sesuai dengan yang yang dikatakan oleh Ibu Lia Septi Arini selaku salah satu orang tua anak rambut gimbal. Ibu Lia Septi Arini adalah salah satu orang tua yang tidak mengikuti Ruwatan Rambut Gimbal di dalam DCF. Beliau memilih untuk tetap melaksanakan Ruwatan Rambut Gimbal secara personal karena kasihan dengan anaknya. Beliau mengatakan, kasihan pada anaknya jika harus melihat anaknya dipakaikan kain kafan saat melaksanakan ritual dan harus menjadi tontonan orang banyak (Zaidi, Nurjaya, Muzadi, 2020).

Selain orang tua, Bapak Sumanto selaku salah satu pemangku adat di Dieng juga merasakan perubahan pada anak rambut gimbal setelah adanya DCF. Bebana si anak rambut gimbal menjadi lebih bermacam-macam dan sulit dikabulkan dalam waktu yang segera. Bebana yang semakin bermacam-macam tersebut disebut membebankan orang tua anak rambut gimbal.

Persepsi yang kontra tersebut juga dirasakan sebagian masyarakat Dieng yang lain. Mereka merasa bahwa dengan adanya DCF, justru partisipasi mereka sebagai warga lokal diabaikan. Masyarakat lokal kecewa karena mereka yang memiliki Ruwatan Rambut Gimbal justru tidak diperkenankan melihat acara tersebut jika tidak memiliki tiket masuk. Kepentingan wisatawan didahulukan daripada kesakralan ritual itu sendiri. Mereka merasa bahwa Ruwatan Rambut Gimbal dalam rangkaian acara DCF dieksploitasi dan nilai budayanya turun menjadi nilai atraksi saja (Setiawan, 2016).

Beberapa penjelasan mengenai persepsi kontra di atas menjelaskan bahwa nilai budaya pada Ruwatan Rambut Gimbal sudah berubah menjadi nilai tukar. Ruwatan Rambut Gimbal diperjualbelikan keunikannya agar menghasilkan keuntungan dalam segi perekonomian. 
Keinginan masyarakat Dieng untuk memperkenalkan keunikan budayanya justru malah merubah nilai dari Ruwatan Rambut Gimbal. Fenomena perubahan nilai ini disebut sebagai komodifikasi.

\section{KESIMPULAN}

Masyarakat Dieng memiliki dua kacamata yang berbeda terhadap Ruwatan Rambut Gimbal. Ruwatan Rambut Gimbal yang dahulu dipandang sebagai tradisi nenek moyang, sekarang berubah menjadi tradisi yang mengalami upaya komodifikasi. Nilai dari Ruwatan Rambut Gimbal berubah karena tuntutan zaman dan keinginan berinovasi dari masyarakat Dieng sendiri. Sayangnya beberapa upaya baik tersebut malah membuat persepsi masyarakat Dieng terhadap Ruwatan Rambut Gimbal menjadi berubah dan kesakralannya menjadi berkurang.

Tujuan baik dari pemerintah, masyarakat Dieng, maupun Pokdarwis menjadi kabur karena adanya kepentingan ekonomi yang diselipkan terhadap upaya menjaga eksistensi Ruwatan Rambut Gimbal. Ketika tujuan baik ini menjadi kabur, yang ditakutkan adalah keberlangsungan Ruwatan Rambut Gimbal. Sehingga muncul pertanyaan kritis selanjutnya. Pertanyaan tersebut adalah, apakah Ruwatan Rambut Gimbal akan tetap sejalan dengan tradisi yang diwariskan nenek moyang, atau berubah menjadi tradisi yang modern dan melunturkan nilai aslinya?

Berdasarkan temuan dalam penelitian Ruwatan Rambut Gimbal dalam Kacamata Masyarakat Dieng, ada beberapa saran yang dapat penulis berikan kepada beberapa pihak terkait. Pertama, bagi masyarakat Dieng, penulis berharap masyarakat Dieng dapat berpartisipasi aktif dalam pelestarian Ruwatan Rambut Gimbal. Agar tercapai persepsi yang sama, masyarakat Dieng dapat membuka forum dengan penyelenggara DCF agar acara yang dilaksanakan di DCF tidak akan melunturkan nilai budaya Ruwatan Rambut Gimbal.

Kedua, bagi panitia penyelenggaran DCF dan Pemerintah Daerah Kabupaten Wonosobo. Sebaiknya sebelum menyelenggarakan Ruwatan Rambut Gimbal di dalam rangkaian acara DCF panitia penyelenggara dan Pemerintah Daerah Kabupaten Wonosobo mengadakan diskusi dengan masyarakat Dieng terlebih dahulu. Hal ini untuk meminimalisir perubahan nilai budaya dan kesakralan dari Ruwatan Rambut Gimbal itu sendiri. Ritual Ruwatan Rambut Gimbal boleh saja diperkenalkan kepada khalayak luas, namun sebisa mungkin kesakralan dan segala kepercayaannya tetap dijaga.

Terakhir, bagi peneliti selanjutnya, penulis berharap peneliti selanjutnya dapat

menggali informasi lebih dalam mengenai Ruwatan Rambut Gimbal dengan metode pengumpulan data wawancara dan tinggal langsung dengan masyarakat Dieng. Hal ini dikarenakan penelitian ini terdampak pandemi covid-19 sehingga tidak memungkinkan peneliti untuk datang dan tinggal langsung bersama masyarakat Dieng. Maka dari itu penelitian ini terbatas karena dilakukan dengan metode literature review.

\section{DAFTAR PUSTAKA}

Arif, Moh. Choirul, Andin Faturrahman. 2013. Makna Simbolik Ruwatan Cukur Rambut Gembel di Desa Dieng Kejajar Wonosobo. Jurnal Ilmu Komunikasi Vol.3 no. 2 
BPNB DIY. 2018. Ruwatan, Membuang Sengkala dalam Tradisi Budaya Jawa. Diakses pada tautan https://kebudayaan.kemdikbud.go.id/bpnbyogyakarta/ruwatan-membuangsengkala-dalam-tradisi-budaya-jawa/

Damayanti, Puspa Ayu. 2011. Dinamika Perilaku "Nakal" Anak Berambut Gimbal di Dataran Tinggi Dieng. Jurnal Psikologi Islam, Vol. 8 no. 2

Febriyanto,A, Riawanti,S, Gunawan,B. 2017. "Mitos Rambut Gimbal: Identitas Budaya dan Komodifikasi di Dataran Tinggi Dieng". Indonesian Journal of Antropology, volume 2 no 1

Holis,N. 2019. "Tradition of Dreadlocks Shaving Ritual (Gimbal) in Dieng Plateau Wonosobo".Metaphore. Vol 1 No 1.

Liliweri, Alo. 2011. Komunikasi Serba Ada Serba Makna. Jakarta: Kencana

Mc. Quail. 2011. Teori Komunikasi Massa Mc. Quail (edisi 6). Jakarta: Salemba Humanika

Muslih, Basthoumi. 2020. Urgensi Komunikasi Dalam Menumbuhkan Motivasi di Era Pandemi Covid-19. Jurnal Penelitian Manajemen Terapan, Vol. 5 no. 1

Samovar, Larry A., Porter, E.R, McDaniel, E.R. Komunikasi Lintas Budaya (Communication Between Cultures) Edisi 7. 2014. Jakarta: Salemba Humanika.

Satria, Eki. 2017. Tradisi Ruwatan Anak Gimbal di Dieng. Jurnal Warna Vol 1. No. 1

Setiawan, Agung. 2016. "Dieng Culture Festival and its Culture Conservation Dilemma". Advances in Economics, Business and Management Research. Vol 28

Soehadha, Moh. 2013. Ritual Rambut Gembel dalam Arus Ekspansi Pasar Pariwisata. Jurnal Walisongo, vol. 21 no. 2

Sukanto, Otto. 2004. Dieng Poros Dunia (Menguak Jejak Peta Surga yang Hilang). Yogyakarta: IRCiSoD

Zaidi, In'am, Nurjaya, Muhamad M. Muzadi. 2020. Eksistensi Ruwatan Rambut Gimbal di Desa Dieng Kulon, Kecamatan Batur, Kabupaten Banjarnegara. Jurnal Antropologi Sosial dan Budaya. Volume 6 no. 1 